\title{
Successfull Level Of Artificial Insemination On Beef Cattle In Purwodadi District, Musirawas Regency
}

\author{
Sadjadi $^{1}$, Ririn Novita ${ }^{1}$, Eko Triawan ${ }^{1}$ \\ ${ }^{1}$ Dosen Prodi Peternakan Fakultas Pertanian Universitas Musi Rawas Jl. Sultan Mahmud \\ Badaruddin II Kel. Air Kuti I, Lubuklinggau-31628 E-mail : sadjadi_71@yahoo.co.id
}

\begin{abstract}
The purpose of this study was to see the success rate of Artificial Insemination on beef cattle in Purwodadi district, Musi Rawas Regency. The parameters observed is Service per Conception (S/C), Conception Rate (CR), Non Raturn Rate (NRR) and Calving Interval (CI). Survey method is used in this study by taking all area of Purwodadi district as the observed area because of its livestock population then analysed by using Slovin Formula to obtain 93 samples. The results of this study concluded that the Conseption Rate $(\mathrm{C} / \mathrm{R})$ in Purwodadi District was very good because it was obtained 70.96\%. Figures for S/C in Purwodadi subdistrict showed an average of 1.4. As for the NRR value in Purwodadi Subdistrict, NRR(0-30) obtained a percentage of 70.96\%. NRR(31-60) obtained $93.54 \%$ and NRR(61-90) obtained $100 \%$. The value of the Calving Interval (CI) is very good, reaching an average of 14.7 or 14 months 7 days.
\end{abstract}

Keywords: Artificial insemination, Purwodadi district, Beef Cattle, Success Rates

\section{PENDAHULUAN}

Sapi potong merupakan salah satu komoditas ternak strategis yang dapat mendukung stabilitas nasional. Produksi daging nasional belum mampu mengimbangi permintaan konsumen di dalam negeri, sehingga memacu peningkatan jumlah impor daging maupun sapi bakalan dari negara lain. Peningkatan populasi dan produksi ternak guna mencukupi kebutuhan dalam negeri, ekspor dan mengurangi impor, merupakan salah satu tujuan pembangunan peternakan menuju swasembada protein hewani. Hal ini didasarkan kenyataan bahwa laju pertumbuhan ternak cenderung lambat dan tidak sejalan dengan peningkatan permintaan daging nasional dengan laju 6-8\%/tahun (Thalib et.al, 2003). Pada tahun 2017 produksi daging nasional mencapai $2.169 .703 \mathrm{~kg}$,atau baru tercapai $63 \%$ dan kekurangan dicukupi melalui impor sebanyak 37\%. Pasokan impor daging diprediksikan semakin meningkat dan mencapai 70\% pada tahun 2020 (Mariyono et.al, 2013).

Populasi ternak sapi potong di Kabupaten Musi Rawas pada tahun 2017 berjumlah 24.449 ekor, sedangkan untuk produksinya sebanyak 912.292 ton dan untuk konsumsinya 
sejumlah 912.291 ton (Badan Pusat Statistik Kab.Mura, 2017).Untuk meningkatkan populasi ternak sapi diperlukan peningkatan efisiensi reproduksi dan fertilitas ternak (Hafez dan Hafez, 2008).

Menurut Tambing et.al (2001), bahwa produktivitas dari setiap hewan domestik termasuk sapi tergantung pada kemampuan reproduksinya, ternak yang kecepatan reproduksinya tinggidan disertai dengan seleksi yang baik dalam perkawinannya akan dapat meningkatkan produksi hasil ternaknya, dan inseminasi buatan (IB) merupakan salah satu cara untuk mencapai peningkatan produktivitas tersebut.

Inseminasi buatan adalah usaha manusia memasukkan sperma ke dalam saluran reproduksi betina dengan menggunakan peralatan khusus. Proses reproduksi yang berjalan normal akan diikuti oleh produksi ternak yang baik pula. Semakin tinggi kemampuan reproduksi, maka semakin tinggi kemampuan produktivitas ternak tersebut. Usaha untuk merealisasikan peningkatan produksi daging dan susu, pemerintah berusaha menjalankan program IB. Melalui teknologi (IB) ini peternak dapat memiliki ternak yang berkualitas tanpa harus memiliki pejantan unggul (Hafez dan Hafez, 2008).

Program IB di usaha sapi potong rakyat di Sumatera Selatan, Jateng, DIY dan Bali menunjukkan bahwa $>50 \%$ peternak masih menghendaki program IB dilanjutkan, namun permasalahannya masih terjadinya kawin berulang kali (Affandhy et.al, 2006). Menurut Bamualim (2003) pengembangan peternakan di suatu wilayah perlu mempertimbangkan dan mengukur potensi wilayah tersebut. Potensi produksi ternak banyak tergantung pada daya dukung makanan ternak, sehingga pengembangan suatu peternakan memerlukan data tentang populasi, luas lahan garapan, rawa dan padang rumput yang ada di daerah tersebut.

Berdasarkan Data Badan Pusat Statistik (BPS) Tahun 2018, tercatat bahwa Kecamatan Purwodadi terdiri dari 9 Desa dan 2 kelurahan. Kedua kelurahan tersebut yaitu Kelurahan Mangunharjo dan Kelurahan Purwodadi. Untuk sektor peternakan penduduk Purwodadi banyak mengusahakan sapi untuk ternak besar, kambing untuk ternak kecil serta unggas dan perikanan. Jumlah ternak besar yang ada di Kecamatan Purwodadi yaitu sapi sebanyak 2.337 ekor, kambing berjumlah 418 ekor dan kerbau 44 ekor. Untuk produksi daging kambing yaitu sebesar $6.108 \mathrm{~kg}$, dan produksi daging sapi $59.059 \mathrm{~kg}$.

Tingkat keberhasilan IB sangat dipengaruhi oleh empat faktor yang saling berhubungan dan tidak dapat dipisahkan satu dengan lainnya yaitu pemilihan sapi akseptor, pengujian kualitas semen, akurasi deteksi birahi oleh para peternak dan keterampilan inseminator. Hasil survei eksistensi IB di wilayah sentra bibit menunjukkan bahwa perlu 
dilakukan perbaikan terhadap infrastruktur IB sedangkan di wilayah pengembangan dibutuhkan perbaikan teknis dalam pelaksanaan IB (Affandhy et.al, 2006). Dalam hal ini inseminator dan peternak merupakan ujung tombak pelaksanaan IB sekaligus sebagai pihak yang bertanggung jawab terhadap berhasil atau tidaknya program IB di lapangan.Susilo (2005) berpendapat bahwa evaluasi efisiensi kegiatan IB yang sudah lazim dilakukan yaitu $\mathrm{S} / \mathrm{C}, \mathrm{CR}$, dan NRR, semakin baik angka dari ketiga parameter tersebut maka tujuan dari bioteknologi IB akan tercapainya efisiensi reproduksi akan semakin baik yang dapat mempengaruhi perkembangan populasi ternak sapi pada suatu wilayah. Berdasarkan latar belakang tersebut maka dibutuhkan suatu penilaian tentang keberhasilan pelaksanaan IB di Kecamatan Purwodadi.

Berdasarkan uraiaun diatas maka perlu dilakukan penelitian untuk mengetahui dan mengevaluasi tingkat keberhasilan Inseminasi Buatan pada sapi potong di Kecamatan Purwodadi Kabupaten Musi Rawas.

\section{METODE}

\section{Tempat dan Waktu}

Penelitian ini telah dilaksanakan di Kecamatan Purwodadi Kabupaten Musi Rawas. Pada bulan April 2019

\section{Bahan dan Alat}

Bahan yang digunakan dalam penelitian ini adalah, 1) Kartu IB sapi potong yang telah di Inseminasi pada periode tahun 2018, 2). Straw sapi Bali, Straw sapi Simmental, dan Straw sapi Limosin. Alat yang digunakan adalah, 1). Alat tulis, 2). Alat hitung, 3). Buku, 4). Kuisioner.

\section{Metode Penelitian}

Metode penelitian yang digunakan dalam penelitian ini adalah observasi langsung di lapang dengan metode pengambilan sampel secara sengaja (purposive sampling) dengan ketentuan sapi betina indukan yang masuk dalam akseptor IB di Kecamatan Purwodadi dibuktikan dengan adanya kartu recording IB yang dimiliki peternak, data yang dikumpulkan terdiri dari data primer dan data sekunder. Data primer diperoleh melalui pengamatan dan wawancara dengan peternak dan inseminator untuk dijadikan responden. Data primer yang diambil meliputi identitas peternak, umur ternak, jenis sapi, dan pengetahuan peternak dalam sistem pemeliharaan induk. Data sekunder didapat dari data recording IB inseminator 
setempat, studi pustaka dan keterangan dari Dinas Pertanian dan Peternakan Kabupaten Musirawas.

\section{Cara Kerja}

\section{Pemilihan Lokasi}

Lokasi penelitian adalah Kecamatan Purwodadi Kabupaten Musi Rawas yang merupakan salah satu Kecamatan dengan populasi ternak sapi potong cukup banyak di Kabupaten Musi Rawas.

\section{Mempersiapkan Kuisioner}

Kuisioner yang dipakai dalam penelitiaan ini ditanyakan langsung kepada inseminator dan pengambilan data dari peternak, guna mendapatkan data primer untuk menghitung tingkat keberhasilan IB sapi.

\section{Pengambilan Sampel Sapi Potong}

Sampel yang digunakan adalah sapi potong betina produktif yang perkawinannya dengan IB dengan catatan induk tersebut sudah pernah beranak minimal satu kali serta dilihat berdasarkan ukuran tubuh induknya. Jumlah sapi betina yang menggunakan teknologi inseminasi buatan (IB) di Kecamatan Purwodadi yaitu sebanyak 1.409 ekor. Berhubung dengan populasi yang sifatnya menyebar diantara lokasi tersebut, maka dilakukan pengambilan sampel secara Analisis deskriptif denganmenggunakan rumus Slovin menurut Umar (2008) sebagai berikut:

$$
\mathrm{n}=\frac{\mathrm{N} 1}{1+\mathrm{Ne}^{2}}
$$

Dengan keterangan : N= Jumlah Populasi

$$
\mathrm{n}=\text { Jumlah Sampel }
$$

$\mathrm{e}=$ Tingkat Galat $(10 \%)$

Tingkat galat $10 \%$ digunakan dengan dasar jumlah populasi tidak lebih dari 2.000, sehingga jumlah sampel yang didapatkan yaitu.

$$
\begin{aligned}
\mathrm{n} & =\frac{\mathrm{N} 1}{1+\mathrm{Ne}^{2}} \\
& =\frac{1409}{1+1409(10 \%)^{2}} \\
& =\frac{1409}{1+1409(0,1)^{2}} \\
& =\frac{1409}{1+1409(0,01)} \\
& =\frac{1409}{}
\end{aligned}
$$




$$
\begin{aligned}
& 1+14,09 \\
& =\frac{1409}{15,09} \\
& n=93,37=93 \text { ekor }
\end{aligned}
$$

Jumlah sampel yang dipakai adalah 93 ekor sapi potong betina produktif yang sudah diinseminasi.

\section{Pengambilan Data Service per Conception Sapi Potong}

Service per Conception ( $S / C)$ adalah angka yang menunjukkan jumlah inseminasi untuk menghasilkan kebuntingan dari sejumlah pelayanan inseminasi yang dibutuhkan oleh seekor betina sampai terjadi kebuntingan (Feradis, 2010). Pengambilan data (S/C) dilakukan dengan cara melihat dan bertanya langsung kepada inseminator dengan dibuktikan adanya kartu peserta (IB) dan mengambil data dari Dinas Pertanian dan Peternakan Kabupaten Musi Rawas.

Kemudian data dikumpulkan dan akan dihitung dengan rumus :

$$
S / C: \frac{\sum \text { straw yang digunakan }}{\sum \text { ternak betina bunting }}
$$

\section{Pengambilan Data Conception Rate Sapi Potong}

Conception Rate $(C R)$ adalah persentase sapi yang bunting hasil satu kali inseminasi, dua kali inseminasi dan seterusnya (Feradis, 2010). Menghitung nilai variabel Conception Rate (CR) yang diperoleh dari inseminator dan Dinas Pertanian dan Peternakan berdasarkan kartu pelaksanaan (IB) yang diformulasikan dengan rumus:

$$
C R=\frac{\sum \text { ternak betina bunting } I B \text { ke-1 }}{\sum \text { ternak betina diinseminasi }} \times 100 \%
$$

\section{Pengambilan Data Non Return RateSapi Potong}

Non Return Rate (NRR) adalah persentase hewan yang tidak menunjukkan birahi kembali atau bila tidak ada permintaan inseminasi lebih lanjut dalam waktu 28 sampai 35 hari atau 60 sampai 90 hari (Feradis, 2010). Evaluasi menggunakan cara ini merupakan cara paling cepat untuk mengukur keberhasilan pelaksanaan IB yang dihitung dengan menggunakan rumus:

$$
\mathrm{NRR}_{0-30}=\frac{\sum \text { sapi yang di IB- } \sum \text { sapi yang di IB ulang } 1}{\sum \text { sapi yang di IB }} \times 100 \%
$$




$$
\begin{aligned}
& \mathrm{NRR}_{31-60}=\frac{\sum \text { sapi yang di IB- } \sum \text { sapi yang di IB ulang } 2}{\sum \text { sapi yang di IB }} \times 100 \% \\
& \mathrm{NRR}_{61-90}=\frac{\sum \text { sapi yang di IB- } \text { sapi yang di IB ulang } 3}{\sum \text { sapi yang di IB }} \times 100 \%
\end{aligned}
$$

\section{Pengambilan Data Calving Interval}

Calving Interval (CI) adalah jarak antara kelahiran satu dengan kelahiran berikutnya pada ternak betina. Jarak kelahiran (CI) merupakan salah satu ukuran produktivitas ternak sapi untuk menghasilkan pedet dalam waktu yang singkat. Jarak waktu beranak (CI) yang ideal adalah 12 bulan, yaitu 9 bulan bunting dan 3 bulan menyusui. Efisiensi reproduksi dikatakan baik apabila seekor induk sapi dapat menghasilkan satu pedet dalam satu tahun (Ball and Peters, 2004).

Menghitung nilai variabel Calving Interval (CI) yang diperoleh dari inseminator dan Dinas Pertanian dan Peternakan berdasarkan kartu pelaksanaan (IB) yang diformulasikan dengan rumus

$$
C I=\frac{\sum j a r a k \text { beranak }}{\sum \text { ternak betina diinseminasi }}
$$

\section{Parameter yang Diamati}

a) Service per Conception Sapi Potong b) Conception Rate Sapi Potong c) Non Return Rate Sapi Potong d) Calving Interval Sapi Potong

\section{HASIL DAN PEMBAHASAN}

Tingkat keberhasilan Inseminasi Buatan di Kecamatan Purwodadi Kabupaten Musi Rawas dapat digambarkan dengan melihat data Servive per Conception (S/C), Conception Rate (CR), Non Return Rate (NRR) dan Calving interval (jarak beranak).

Untuk melihat data tingkat keberhasilan Inseminasi Buatan pada Sapi Potong di Kecamatan Purwodadi dapat dilihat pada Tabel 1 berikut.

\section{Service per Conception (S/C)}

Tabel 1. IndikatorPengukuran Keberhasilan Inseminasi Buatan Pada Sapi Potong a. Service per Conception

\begin{tabular}{cccc}
\hline No & $\begin{array}{c}\text { Pelayanan Inseminasi } \\
\text { Buatan (kali) }\end{array}$ & Jumlah Sapi (ekor) & $\begin{array}{c}\text { Jumlah Straw } \\
\text { (dosis) }\end{array}$ \\
\hline
\end{tabular}




\begin{tabular}{cccc}
1 & 1 & 66 & 66 \\
2 & 2 & 21 & 42 \\
3 & 3 & 6 & 18 \\
\hline & Jumlah & 93 & 126 \\
\hline
\end{tabular}

Sumber : Data Olahan Hasil Penelitian, 2019

Service per Conception $(S / C)=\frac{\text { jumlah straw yang digunakan }}{\text { jumlah ternak betina bunting }}$

$$
\begin{aligned}
& =\frac{126}{93} \\
& =1,35
\end{aligned}
$$

\section{Conception Rate (CR)}

Conception Rate $=\frac{\text { jumlah ternak betina bunting IB pertama }}{\text { jumlah ternak bunting di inseminasi }} \times 100 \%$

$$
\begin{aligned}
& =\frac{66}{93} \times 100 \% \\
& =70,96 \%
\end{aligned}
$$

\section{Non Return Rate (NRR)}

Tabel 2. Perhitungan Non Return Rate

\begin{tabular}{cccc}
\hline No & Pelayanan IB (kali) & $\begin{array}{c}\text { Jumlah Total } \\
\text { Sapi Bunting } \\
\text { (ekor) }\end{array}$ & Persentase \\
\hline 1 & 1 & 66 & $70,96 \%$ \\
2 & 2 & 87 & $93,54 \%$ \\
3 & 3 & 93 & $100 \%$ \\
\hline
\end{tabular}

Sumber : Data Olahan Hasil Penelitian, 2019

$$
\begin{aligned}
\text { * } N R_{(0-30)} & =\frac{\text { jumlah sapi yang di IB-jumlah sapi yang di IB ulang pertama }}{\text { jumlah ternak bunting di inseminasi }} \times 100 \% \\
& =\frac{93-27}{93} \times 100 \% \\
& =\frac{66}{93} \times 100 \% \\
& =70,96 \%
\end{aligned}
$$

$$
\begin{aligned}
& \text { * } N R R_{(31-60)}=\frac{j u m l a h \text { sapi yang di IB-jumlah sapi yang di IB ulang kedua }}{\text { jumlah ternak bunting di inseminasi }} \times 100 \% \\
& =\frac{93-6}{93} \times 100 \% \\
& =\frac{87}{93} \times 100 \%
\end{aligned}
$$




$$
\begin{aligned}
& =93,54 \% \\
* N R R_{(61-90)} & =\frac{\text { jumlah sapi yang di IB-jumlah sapi yang di IB ulang ketiga }}{\text { jumlah ternak bunting di inseminasi }} \times 100 \% \\
\frac{93-0}{93} \times 100 \% & = \\
= & \frac{93}{93} \times 100 \% \\
= & 100 \%
\end{aligned}
$$

Sedangkan untuk melihat data tingkat keberhasilan Inseminasi Buatan pada Sapi Potong di Kecamatan Purwodadi dapat dilihat pada Tabel 3 berikut.

\section{Jarak Kelahiran / Calving Interval}

Tabel 3. Identifikasi Jarak Kelahiran Sapi Potong yang di IB.

\begin{tabular}{cccc}
\hline No. & Jarak Kelahiran & Jumlah Sapi(ekor) & Perkalian \\
\hline 1 & 12 bulan & 46 & 552 \\
2 & 13 bulan & 4 & 52 \\
3 & 14 bulan & 8 & 112 \\
4 & 15 bulan & 2 & 30 \\
5 & 16 bulan & 1 & 16 \\
6 & 17 bulan & 4 & 68 \\
7 & 18 bulan & 24 & 432 \\
8 & 19 bulan & 1 & 19 \\
9 & 24 bulan & 2 & 48 \\
10 & 36 bulan & 1 & 36 \\
\hline & Jumlah & 93 & 1.365 \\
\hline
\end{tabular}

Sumber : Data Olahan Hasil Penelitian, 2019.

Dari data tabel diatas dapat disimpulkan bahwa jarak beranak pada Sapi Potong di Kecamatan Purwodadi diantaranya yaitu jarak beranak selama 12 bulan sebanyak 46 sampel, jarak beranak 13 bulan sebanyak 4 sample, jarak beranak 14 bulan sebanyak 8 sample, jarak beranak 15 bulan sebanyak 2 sample, jarak beranak 16 bulan sebanyak 1 sample, jarak beranak 17 bulan sebanyak 4 sample, jarak beranak 18 bulan sebanyak 24 sample, jarak beranak selama 19 bulan sebanyak 1 sample, jarak beranak 24 bulan sebanyak 2 sampel dan yang terakhir jarak beranak 36 bulan sebanyak 1 sample. Rata-rata kelahiran $\frac{1365}{93}=14$ bulan 7 hari.

Tingkat keberhasilan Inseminasi Buatan adalah persentase nilai kebuntingan yang dapat dicapai dalam pelaksanaan Inseminasi Buatan dengan melihat beberapa indikator pengukuran keberhasilan yaitu diantaranya angka Service Per Conception, Conception Rate, 
Non Return Rate dan Calving Interval teknik ini telah banyak digunakan untuk melihat keberhasilan pelaksanaan Inseminsi Buatan (Saputra, 2008).

Hal ini sesuai dengan pendapat Susilo (2005) bahwa evaluasi efesiensi kegiatan Inseminasi Buatan yang sudah lazim dilakukan yaitu melihat data Service per conception $(S / C)$, Conception rate $(C R)$ dan Calving interval (jarak beranak), semakin baik angka keempat parameter tersebut maka tujuan dari Bioteknologi IB akan tercapai efesiensi reproduksi akan semakin baik yang dapat mempengaruhi populasi ternak sapi di suatu wilayah.

\section{Service Per Conception (S/C)}

Service Per Conception merupakan jumlah pelayana Inseminasi Buatan seekor betina bunting . Dari hasil penelitian di Kecamatan Purwodadi diperoleh nilai S/C sebesar 1,35 artinya untuk setiap kebuntingan rata-rata di perlukan 1,35 dosis straw. Semakin kecil nilai S/C makan keberhasilan Inseminasi Buatan semakin baik. Jalius (2011) menjelaskan tinggi rendahnya nilai S/C dipengaruhi oleh ketepatan deteksi birahi, ketepatan waktu IB dan kondisi reproduksi ternak betina. Ihsan dan Wahjuningsih (2011) menyatakan tinggi rendahnya nilai $\mathrm{S} / \mathrm{C}$ tidak terlepas dari rata-rata pemberian kandungan nutrisi dalam pakan yang sangat mempengaruhi kondisi reproduksi betina. Apabila S/C rendah, maka nilai kesuburan sapi betina semakin tinggi dan apabila nilai S/C tinggi, maka semakin rendah tingkat kesuburan sapi betina tersebut. Nuryadi dan Wahyuningsih (2011) menyatakan bahwa kisaran normal nilai S/C adalah 1,6 - 2,0. Berdasarkan nilai S/C di Kecamatan Purwodadi tersebut maka tingkat keberhasilan pelaksanaan Inseminasi Buatan sangat baik.

\section{Conception Rate (CR)}

Conception Rate $(C R)$ merupakan persentase kebuntingan sapi betina pada pelaksanaan Inseminasi Buatan pertama dan dapat dijadikan sebagai alat ukur kesuburan ternak. Dikecamatan Purwodadi nilai CR pada Sapi Potong sebesar 70,96 \%. Angka CR pada kelompok ternak dipengaruhi oleh besarnya rata-rata nilai S/C, jika semakin rendah S/C maka CR akan semakin tinggi. Tinggi rendahnya angka konsepsi atau CR disebabkan oleh banyak faktor, salah satunya adalah deteksi birahi. Ketepatan deteksi birahi sangat mempengaruhi nilai CR. Pernyataan tersebut sesuai dengan pendapat Jalius (2011) bahwa nilai CR dipengaruhi oleh ketepatan deteksi birahi dan waktu Inseminasi Buatan. Kesalahan deteksi birahi dapat dikarenakan terjadinya silent heat atau birahi tenang. Susilawati (2004) menyatakan bahwa tinggi rendahnya nilai CR disebabkan oleh banyak tidaknya ternak yang 
kembali birahi setelah Inseminasi Buatan pertama. Kembalinya birahi ternak disebabkan oleh beberapa faktor, salah satunya karena kurangnya perhatian peternak terhadap deteksi birahi dan keterlambatan melapor, sehingga menyebabkan keterlambatan pelaksanaan Inseminasi Buatan. Birahi dipengaruhi oleh pakan yang diberikan. Pada musim kemarau hijauan yang diberikan cenderung berkualitas jelek, sehingga menyebabkan birahi lagi dan berakibat pada rendahnya $\mathrm{CR}$.

Fanani, et. al (2013), menyatakan bahwa CR yang baik mencapai 60-70\%, yang ditentukan oleh kesuburan pejantan, kesuburan betina, dan teknik inseminasi. Berdasarkan nilai CR di Kecamatan Purwodadi sebesar 70,96\% maka angka CR dinyatakan sangat baik.

\section{Non Return Rate (NRR)}

Jalius (2011) menyatakan NRR merupakan gambaranjumlah kebuntingan berdasarkan satu siklus birahi 17-35 hari yang tidak minta kawin kembali setelah di Inseminasi Buatan. Evaluasi keberhasilan Inseminasi Buatan dan kebuntingan ternak dapat dilihat dari timbulnya birahi kembali pada kurun waktu tertentu. Susilawati $\left(2011_{b}\right)$ menjelaskan bahwa NRR merupakan persentase jumlah ternak yang tidak kembali birahi antara 60-90 hari. Susilawati $\left(2011^{\mathrm{a}}\right)$ melakukan evaluasi Inseminasi Buatan dengan perhitungan $\mathrm{NRR}_{0-30}, \mathrm{NRR}_{31-60}$, dan $\mathrm{NRR}_{61-90}$. Sedangkan dalam penelitian ini pengamatan NRR dilakukan di hari 0-30, 31-60 dan $61-90$.

Sapi yang menunjukkan tanda-tanda birahi setelah Inseminasi Buatan pertama dilakukan Inseminasi Buatan kedua, kembali birahi setelah Inseminasi Buatan kedua dilakukan Inseminasi Buatan yang ketiga dan apabila terjadi birahi kembali setelah Inseminasi Buatan ketiga dianggap gagal. Metode NRR berpedoman pada asumsi bahwa sapi yang telah di Inseminasi Buatan dan tidak birahi kembali, maka dianggap bunting (Susilawati, 2011 a) Sedangkan nilai NRR di Kecamatan Purwodadi yaitu $\mathrm{NRR}_{0-30}$ diperoleh persentase yaitu 70,96\%. NRR $31-60$ diperoleh 93,54\% dan $\mathrm{NRR}_{61-90}$ diperoleh $100 \%$. Dengan nilai NRR dilapangan tersebut maka dapat disimpulkan NRR Sapi Potong di Kecamatan Purwodadi sudah baik, karenadari hasilnyatidakjauh berbeda dengan hasil dari penelitian terdahulu yaitu nilai NRR pada 60-90 hari mencapai rata-rata 65-72\% (Robert, 1971 dalam. Feradis 2010).

\section{Calving Interval(CI)}

Calving Interval (CI) adalah jarak antara kelahiran satu dengan kelahiran berikutnya pada ternak betina. Jarak kelahiran (CI) merupakan salah satu ukuran produktivitas ternak sapi untuk menghasilkan pedet dalam waktu yang singkat. jarak waktu beranak (CI) yang 
ideal adalah 12 bulan, yaitu 9 bulan bunting dan 3 bulan menyusui. Efisiensi reproduksi dikatakan baik apabila seekor induk sapi dapat menghasilkan satu pedet dalam satu tahun (Ball and Peters, 2004). Jadi nilai Calving Interval rata-rata di Kecamatan Purwodadi masih kurang baik yaitu 14,7 atau 14 bulan lebih 7 hari, hal ini tidak sejalan dengan pendapat Ball and Peters yaitu pada kisaran 12 bulan yang artinya jarak kelahiran di Kecamatan tersebut kurang baik.

Beberapa hal yang menyebabkan jarak kelahiran lebih lama dari 12 bulan adalah karena peternak mengawinkan lagi sapinya saat pedet umur 5 bulan lebih dengan alasan merasa kasihan karena induknya masih menyusui.

\section{KESIMPULAN}

Berdasarkan data hasil penelitian tersebut dapat disimpulkan bahwa :

a. Conception Rate $(C / R)$ di Kecamatan Purwodadi sangat baik karena di peroleh pada kisaran 60-75\%, yaitu sebesar 70,96\%.

b. Angka S/C rasio di Kecamatan Purwodadi yang rata-rata menunjukkan angka 1,35 artinya tingkat keberhasilan insemiasi buatan pada ternak tersebut sangat baik.

c. Sedangkan untuk nilai NRR di Kecamatan Purwodadi yaitu NRR $_{0-30}$ diperoleh persentase yaitu 70,96\%. $\mathrm{NRR}_{31-60}$ diperoleh $93,54 \%$ dan $\mathrm{NRR}_{61-90}$ diperoleh $100 \%$.

d. Nilai Calving Interval(CI) kurang baik yaitu mencapai rata-rata 14,7 atau 14 bulan lebih 7 hari.

e. Inseminasi buatan merupakan program yang telah dikenal oleh peternak sebagai teknologi reproduksi ternak yang efektif. Inseminasi Buatan sudah cukup lama dikenal oleh masyarakat Kecamatan Purwodadi, hal ini mengindikasikan bahwa tingkat keberhasilan IB di Kecamatan Purwodadi cukup baik.

\section{DAFTAR PUSTAKA}

Affandhy L, D Pamungkas, DB Wijono, PW Prihandini, P Situmorang, dan WC Pratiwi. 2006. Peningkatan Produktivitas Sapi Potong Melalui Efisiensi Reproduksi. Laporan akhir. Loka Penelitian Sapi Potong.

Badan Pusat Statistik Kabupaten Musi Rawas. 2017. Laporan Tahunan 2017. Pemerintah Kabupaten Musi Rawas. Sumatera Selatan

Badan Pusat Statistik Kabupaten Musi Rawas. 2018. Laporan Tahunan 2018. Pemerintah Kabupaten Musi Rawas. Sumatera Selatan 
Ball,P.J, H, A.R. Peters. 2004. Reproduction in Cattle. Third Edition Blackwell Publishing. Victoria. Australia

Bamualim, A. 2003. Potensi Pengembangan Peternakan di Sumatera Selatan. Disampaikan dalam acara pengukuhan Pengurus Ikatan Sarjana Peternakan Cabang Sumatera Selatan. Palembang, 25 Mei 2003. Balai Pengkajian Teknologi Pertanian (BPTP). Palembang. Sumatera Selatan

Fanani, S., Subagyo , Y.B.P., dan Lutojo. 2013. Kinerja Reproduksi Sapi Perah Peranakan Friesian Holstein (PFH) di Kecamatan Pudak, Kabupaten Ponorogo. Fakultas Pertanian. Universitas Sebelas Maret. Surakarta.

Feradis, 2010. Bioteknologi Reproduksi pada Ternak. Alfabeta. Bandung.

Hafez, E. S. E. dan B. Hafez. 2008. Semen Evaluation in Reproduction In Farm Animals. 7th edition. Lippincott Wiliams and Wilkins. Maryland, USA

Ihsan, M.N dan S. Wahjuningsih. 2011. Penampilan Reproduksi Sapi Potong di Kabupaten Bojonegoro. Jurnal Ternak Tropika. 12 (2) : 15-24.

Jalius. 2011. Hubungan mortalitas progresif dan keutuhan membran sperma dalam semen beku sapi Bali dengan keberhasilan inseminasi. Agrinak. 01 (1) : 44- 46

Mariyono, E. Romjali, D.B. Wijono dan Hartati 2013. Paket Rakitan Teknologi Hasil-Hasil Penelitian Peternakan untuk Mendukung Indonesia Mencapai Swasembada Sapi Potong.

Sapurta A. G. S. 2008. Evaluasi Program Inseminasi Buatan Pada Sapi Bali Dikecamatan Skanto Kabupaten Jaya Pura.

Susilawati T. 2004. Keberhasilan IB menggunakan semen sexing setelah dibekukan. Seminar nasional teknologi peternakan dan veteriner : 199-202

Susilawati,T. 2011 a . Tingkat Keberhasilan Inseminasi Buatan Dengan Kualitas dan Deposisi Semen Yang Berbeda pada Sapi Peranakan Ongole. J. Ternak Tropika 12 (2) : 15-24

Susilawati, T. 2011 ${ }^{\mathrm{b}}$. Spermatology. Universitas Brawijaya (UB) press. Malang

Susilo, T. 2005. Efisiensi Reproduksi Program Inseminasi Buatan Terhadap Sapi Lokal pada Daerah Lahan Basah dan Kering di Kabupaten Magelang Provinsi Jawa Tengah. Faktultas Peternakan Diponegoro. Tesis

Tambing SN, Toelihere MR, Yusuf TL, Sutama IK. 2001. Kualitas semen beku kambing peranakan Etawah setelah ekuilibrasi. Hayati 8:70-75

Thalib. C., Entwistie, K., Siregar, A. Budiarti-Turner, S. And Lindsay, D. 2003. Survey of populationa and production dynamics of Bali cattle and existing breeding programs in Indonesia. In. K. Entwistle and D.R. Lindsay(Eds.). Strategies to Improve Bali Cattle in Eastern Indonesia. ACIAR Proc. Non

Umar, S. dan Maharani, M. 2005. Pengaruh Berbagai Waktu Ekuilibrasi Terhadap Daya Tahan Sperma Sapi Limousin dan Uji Kebuntingan. Jurnal Agribisnis Peternakan. 1 (1): 17-21. 